\title{
Assessment of Adolescent Perceptions on Parental Attitudes on Different Variables
}

\author{
Evren Ersoy \\ Correspondence: Guidance and Psychological Counseling, College of Education, Yildiz Technical University, Istanbul, \\ Turkey
}

Received: July 3, 2015 Accepted: July 20, 2015 Online Published: July 29, 2015

doi:10.11114/jets.v3i5.929

URL: http://dx.doi.org/10.11114/jets.v3i5.929

\begin{abstract}
The purpose of this study is to examine secondary school student perceptions of parental attitudes with regards to specific variables. Independent samples $t$ test for parametric distributions and one-way variance analysis (ANOVA) was used for analyzing the data, when the ANOVA analyses were significant Scheffe test was conducted on homogeneous variance and Tamhane's T2 test was conducted when the analyses were not homogeneous. Kruskall Wallis H test was conducted on non-parametric distributions and Mann Whitney-U test was conducted when the Kruskall Wallis $\mathrm{H}$ analyses were significant. It was observed that the democratic attitude dimension, which is a sub-dimension of parental attitudes that students perceive, does not significantly differ from the gender, number of siblings and income level variables; but is significantly different according to the parental educational status, whether parents are alive and marital status of the parents' variables. It was observed that the protective-willing dimension, which is a sub-dimension of parental attitudes that students perceive, does not significantly differ from the gender, income level, whether parents are alive and marital status of the parents' variables; but is significantly different according to the parental educational status and number of siblings' variables. It was observed that the authoritarian dimension, which is a sub-dimension of parental attitudes that students perceive, does not significantly differ from the educational status of mother, number of siblings, income level, whether parents are alive and marital status of parents variables; but is significantly different according to the gender and educational status of the father variables.
\end{abstract}

Keywords: adolescent, parental attitudes, secondary school student, Turkey

\section{Introduction}

Among the development periods, adolescence is defined as the most susceptible period to external influences (Hummel \& Gross, 2001). Individuals are constantly in interaction with their families, friends and teachers throughout this period. During this period, the adolescent is deeply concerned with what others think about him and consciously or unconsciously shapes his behaviors by internalizing especially his parents' attitudes (Gulacti, 2009). Family is the small unit that is created by individuals who are closely related and bond together and who unite in order to perform their functions and objectives. They are connected to each other with such strong bonds that a small change in one component strikes the whole system (Kilicaslan, 2001). The first social environment of a child is with his family. Interpersonal relationships and concepts emerge under the influence of the family. The contribution that the family has on the emotional and social development and education of the child stems from the relationship between the child and other family members. These relationships are under the influence of both the attitudes and behavior patterns of the family members towards the child and also all other patterns within the family. The family structure, size, socio-economic status and cultural status in which the child belongs will affect his initial social experiences and thus his emotional and social developments (Bayraktar, 2007; Budd et al., 2012; Yavuzer, 2012). The quality of the family environment is closely related with the child having a stable and compatible personality. The relationship which the child enters into with his parents being based on trust forms the basis of the relationships in which he will enter with the external world in the future (Branch, 1986; Kuzgun \& Eldeleklioglu, 2005; Peterson, 1961). In addition, children who have frequently been exposed to punishment and violence from their parents behave the same way to their own children (Baltas, 2003).

The child raising attitudes of the parents is a crucial variable which affects child's socialization. The parents being democratic or egalitarian, oppressive authoritarian or over protective causes children to develop various social behaviors. Children who are raised in democratic and egalitarian environments will have good relationships with their 
surroundings and also self-reliance (Kaya et al., 2012; Kulaksizoglu, 2008). For example, children who are raised up in democratic and tolerant settings are children who are more active, more sociable, who offer creative ideas and who express themselves comfortably in their relationships (Yavuzer, 2011). On the other hand, children who are raised up under tight control and under changing educational methods tend to make themselves accepted with protest, depression and violence and have difficulties in expressing themselves (Birsen, 2008; Parker \& Roy, 2001).

Kuzgun and Eldeleklioglu (2005) grouped parental attitudes under three categories. These are; Democratic Parental Attitudes, Protective-Willing Parental Attitudes and Authoritarian Parental Attitudes.

Democratic parental attitudes are based on recognizing the child and respecting their desires (Demiriz \& Ogretir, 2007). Children who are raised up like this have advanced sense of trust, can freely express their ideas, are active, can take responsibilities, respect themselves and others, are willing to improve and realize themselves and to produce creative ideas (Kulaksizoglu, 2008). In addition, children who are raised in democratic families are more inclined to personality development and the democratic environment provides the child both freedom and also encourages them to express themselves and gain experiences. An individual who is raised up in such a setting is more active, fearless and independent (Ozguven, 2001).

Authoritarian parents tend to shape the child according to their own moulds. The child is constantly under control. Children who are raised in such environments have a moderate level of success at schools, low levels of self-respect, high level of fear of being negatively criticized, high risk of going in depression and low coping skills. In addition, small mistakes of the child are never unnoticed, are emphasized immediately and sought for a settlement (Sargin, 2001; Erdogan \& Ucukoglu, 2011). Parents who display this attitude think the child's respect to his mother and father is a virtue. Most of them do not verbally encourage and believe that the words of the mother and father should be accepted as the truth (Kulaksizoglu, 2008).

Over protective parents show excessive control and care towards their children. As a result, the child can be an individual who is over dependent on others, who does not have self-confidence and who has frustrations (Yorukoglu, 2011). The dependency which lasts throughout a lifetime negatively affects psycho-social maturity and hinders the child to become self-sufficient. Over protectiveness of the parents also affects the child's success and orientation in school (Yavuzer, 2013). Children who have failed to improve their sociable skills under over protectiveness and under the dependent relationships which are caused by excessive tolerance have insufficient levels of self-confidence (Eldeleklioglu, 2004).

Scholars argue that parental attitudes play a crucial role in child education and child personality development (Sargin, 2001; Erdogan \& Ucukoglu, 2011).. Thus, the purpose of this study is to examine whether secondary school student parents' attitudes differ with regards to gender, educational status of parents, number of siblings, economic status of the family, whether the parents are alive and marital status of the parents. This study is believed to enable a discussion on the factors that lead to negative or positive perceptions of secondary school students about their parents' attitudes and on what could be done about this. Following research questions used for this study;

1. Do student perceptions on parental attitudes (democratic attitude, protective-willing attitude, authoritarian attitude) differ according to gender?

2. Do student perceptions on parental attitudes (democratic attitude, protective-willing attitude, authoritarian attitude) differ according to the educational status of the mother?

3. Do student perceptions on parental attitudes (democratic attitude, protective-willing attitude, authoritarian attitude) differ according to the educational status of the father?

4. Do student perceptions on parental attitudes (democratic attitude, protective-willing attitude, authoritarian attitude) differ according to the number of siblings?

5. Do student perceptions on parental attitudes (democratic attitude, protective-willing attitude, authoritarian attitude) differ according to the economic status of the family?

6. Do student perceptions on parental attitudes (democratic attitude, protective-willing attitude, authoritarian attitude) differ according to whether the parents are alive?

7. Do student perceptions on parental attitudes (democratic attitude, protective-willing attitude, authoritarian attitude) differ according to the marital status of the parents?

\section{Method}

\subsection{Research Design}

The relational survey model was used in this study. Relational screening model is a model which aims at determining whether there is a change and its level among two or more variables (Creswell, 2012). Relationships which are identified with the screening model do not indicate a cause-effect relationship, but enables to identify another variable once the 
condition of one variable is defined (Karasar, 2014).

\subsection{Population and Sample}

The study group of the study was selected with the simple random sampling method. The sample of the study consists of 526 students studying in year 6 and 7 in nine different secondary schools in Fatih district of Istanbul. The study group consists of 249 males and 276 females. 272 of the participants are in year 6 and 254 of the participants are in year 7.

\subsection{Data Collection Instruments}

\subsubsection{Personal Information Form}

The personal information questionnaire which was prepared by the researcher in order to identify the students according to their various features consists of 7 questions. These questions provide information about the independent variables of the study. These questions are related to; gender, educational status of the mother, educational status of the father, number of siblings, economic condition of the family, whether the parents are alive and the marital status of the parents.

\subsubsection{Perceived Parental Attitudes Scale (ABT)}

Parental Attitude Scale developed by Kuzgun and Eldeklioglu (2005) was used in the study in order to determine the parental attitudes that the students perceive. The scale consists of total 40 questions and three sub-dimensions. These are democratic parental attitudes, authoritarian parental attitudes and protective parental attitudes. High scores from the scales indicate that the parental attitude of the dimension is high. Internal consistency coefficients of the reliability of the Perceived Parental Attitudes scale are; .89 for the democratic attitude, .82 for the protective-willing attitude and .78 for the authoritarian attitude.

\subsection{Data Collection and Analysis}

The study was conducted during the 2012-2013 academic period. Permissions were issued from the creators of the scales which were to be used in the data collection process. Human Subject (IRB\# B.08.MEM.0.34.14.00-020-/157453) was issued on 28 November 2012 from the Directorate of National Education. The schools in which the study was to be conducted were selected with the random sampling method. Counselors working in the sample schools were informed and asked for help as implementers. The data was collected based on voluntariness. The study subject was explained to the students before each practice. The purpose and importance of the study and that the personal identifying information of the students was not necessary along with the data being kept secret was acknowledged to the students. A notice explaining how the data collection instruments were to be answered was provided for the students. The students were observed to complete the questionnaire in 35 minutes. Data was analyzed with the SPSS 16.0 software. Independent samples $t$ test was conducted in order to determine whether secondary school student perceptions on parental attitudes were significantly different according to the gender and marital status of the parents variables. One-way variance analysis (ANOVA) was conducted in order determine whether student perceptions on parental attitudes were significantly different according to the educational status of the mother, number of siblings and perceived economic status of the family variables. When the ANOVA analyses were significant, Scheffe analysis was conducted on homogeneous variances and Tamhane's T2 analysis was conducted on non-homogeneous variances. Kruskall Wallis H analysis was conducted in order to determine whether students' perceptions on parental attitudes were significantly different according to the educational status of the father variable. The Mann Whitney-U analysis was used when the Kruskall Wallis H analyses resulted as significant. Mann Whitney-U analysis was conducted in order to determine whether student perceptions on parental attitudes were significantly different according to whether the parents are alive variable.

\section{Results}

The results of finding were shown on Table 1. According to the findings 249 (47.3\%) of students are males and 277 $(52.7 \%)$ of them are females. As for students' mothers, 60 (11.4\%) of the mothers did not graduate from any school, 190 $(36.1 \%)$ of them graduated from primary school, $105(20 \%)$ of them graduated from middle school, $135(25.7 \%)$ of them graduated from high school and $36(6.8 \%)$ of them graduated from university or above. As for students fathers, $27(5.1 \%)$ of the fathers did not graduate from any school, 156 (29.7\%) of them graduated from primary school, $128(24.3 \%)$ of them graduated from middle school, 137 (26\%) of them graduated from high school and 78 (\%14.8) of them graduated from university or above. $56(10.6 \%)$ of the students have 1 sibling, $216(41.1 \%)$ of the students have 2 siblings, $133(25.3 \%)$ of the students have 3 siblings, and 121 (23\%) of the students have 4 or more siblings. 73 (13.9\%) of the students stated that they were in the low and lower middle income level, 314 (59.7\%) of the students stated that they were in the middle income level and $139(26.4 \%)$ of the students stated that they were in the upper and high income level. $514(97.7 \%)$ of the students stated that their parents were alive and $12(2.3 \%)$ of the students stated that either their father or mother was dead. $490(93.2 \%)$ of the students stated that their parents were married and $36(6.8 \%)$ of the students stated that their parents were divorced. 
Table1. Findings on the General Structure of the Group

\begin{tabular}{|c|c|c|}
\hline & $\mathrm{N}$ & Percentage $(\%)$ \\
\hline \multicolumn{3}{|l|}{ Gender } \\
\hline Male & 249 & 47.3 \\
\hline Female & 277 & 52.7 \\
\hline \multicolumn{3}{|l|}{ Mother's Education Level } \\
\hline Not a graduate of any school & 60 & 11.4 \\
\hline Primary School & 190 & 36.1 \\
\hline Middle School & 105 & 20.0 \\
\hline High School & 135 & 25.7 \\
\hline University and above & 36 & 6.8 \\
\hline \multicolumn{3}{|l|}{ Father's Education Level } \\
\hline Not a graduate of any school & 27 & 5.1 \\
\hline Primary School & 156 & 29.7 \\
\hline Middle School & 128 & 24.3 \\
\hline High School & 137 & 26.0 \\
\hline University and above & 78 & 14.8 \\
\hline \multicolumn{3}{|l|}{ Number of Siblings } \\
\hline 1 Sibling & 56 & 10.6 \\
\hline 2 Siblings & 216 & 41.1 \\
\hline 3 Siblings & 133 & 25.3 \\
\hline 4 Siblings and More & 121 & 23.0 \\
\hline \multicolumn{3}{|l|}{ İncome Level } \\
\hline Low and below middle class & 73 & 13.9 \\
\hline Middle class & 314 & 59.7 \\
\hline Upper and high & 139 & 26.4 \\
\hline \multicolumn{3}{|l|}{ Are your parents alive? } \\
\hline Alive & 514 & 97.7 \\
\hline Dead & 12 & 2.3 \\
\hline \multicolumn{3}{|l|}{$\underline{\text { Parents' marital status }}$} \\
\hline Married & 490 & 93.2 \\
\hline Divorced & 36 & 6.8 \\
\hline $\begin{array}{l}\text { Total } \\
526 \\
\end{array}$ & & 100 \\
\hline
\end{tabular}

This section of the study focuses on the analysis results regarding whether parental attitudes that students perceive differ significantly according to specific variables.

Table 2. Results of the Independent Samples T Test Conducted to Determine Whether Parental Attitudes Differ according to the Gender of the Students

\begin{tabular}{|c|c|c|c|c|c|c|c|c|}
\hline \multirow[b]{2}{*}{ Score } & \multirow[b]{2}{*}{ Groups } & \multirow[b]{2}{*}{$N$} & \multirow[b]{2}{*}{$\overline{\mathrm{X}}$} & \multirow[b]{2}{*}{$S S$} & \multirow[b]{2}{*}{$\mathrm{Sh}_{\bar{x}}$} & \multicolumn{3}{|c|}{$\begin{array}{ll}t & \text { Test } \\
\end{array}$} \\
\hline & & & & & & $\boldsymbol{t}$ & $S d$ & $p$ \\
\hline Democratic attitude & $\begin{array}{c}\text { Male } \\
\text { Female }\end{array}$ & $\begin{array}{l}249 \\
277\end{array}$ & $\begin{array}{l}4.17 \\
4.28\end{array}$ & $\begin{array}{l}0.66 \\
0.66\end{array}$ & $\begin{array}{l}0.04 \\
0.04\end{array}$ & -1.94 & 524 & .053 \\
\hline Protective/Demanding attitude & $\begin{array}{c}\text { Male } \\
\text { Female }\end{array}$ & $\begin{array}{l}249 \\
277 \\
\end{array}$ & $\begin{array}{l}3.06 \\
3.01 \\
\end{array}$ & $\begin{array}{l}0.67 \\
0.67\end{array}$ & $\begin{array}{l}0.04 \\
0.04 \\
\end{array}$ & .878 & 524 & .381 \\
\hline \multirow[t]{2}{*}{ Authoritarian attitude } & Male & 249 & 2.28 & 0.74 & 0.05 & \multirow{2}{*}{3.969} & \multirow{2}{*}{524} & \multirow{2}{*}{.000} \\
\hline & Female & 277 & 2.03 & 0.73 & 0.04 & & & \\
\hline
\end{tabular}

It is evident on Table 2. that according to the Independent Samples T Test which was conducted to determine whether parental attitudes differ with regards to student gender, there is no significant difference between the arithmetic averages of the democratic attitude dimension $(\mathrm{t}=-1.94 ; \mathrm{p}>.05)$ and the protective-willing attitude dimension $(\mathrm{t}=.878 ; \mathrm{p}>.05)$. However, the difference between the arithmetic averages of the groups for the authoritarian attitude dimension was significantly in favor of the male students $(t=3.969 ; p<.001)$. In other words male students perceive parental attitudes as authoritarian more than female students. 
Table 3. Results of the One-Way Variance Analysis (ANOVA) Conducted to Determine Whether Parental Attitudes Differ According to the Educational Status of the Mother

\begin{tabular}{|c|c|c|c|c|c|c|c|c|c|c|}
\hline & $f, \overline{\mathrm{x}}$ and $s s$ Val & & & & & ANC & IA Re & ults & & \\
\hline Scores & Group & $N$ & $\overline{\mathrm{X}}$ & $S S$ & Var. K. & $K T$ & $S d$ & KO & $F$ & $p$ \\
\hline \multirow{8}{*}{$\begin{array}{l}\text { Democratic } \\
\text { attitude }\end{array}$} & Not a graduate of any school & 60 & 4.10 & 0.65 & Intergroup & 5.12 & 4 & 1.28 & \multirow{6}{*}{3.04} & \multirow{6}{*}{0.02} \\
\hline & Primary school & 190 & 4.23 & 0.69 & in-group & 219.26 & 521 & 0.42 & & \\
\hline & Middle school & 105 & 4.11 & 0.68 & Total & 224.38 & 525 & & & \\
\hline & High school & 135 & 4.33 & 0.60 & & & & & & \\
\hline & University and above & 36 & 4.43 & 0.49 & & & & & & \\
\hline & Total & 526 & 4.23 & 0.65 & & & & & & \\
\hline & Not a graduate of any school & 60 & 3.25 & 0.55 & Intergroup & 6.38 & 4 & 1.60 & \multirow{6}{*}{3.62} & \multirow{6}{*}{0.01} \\
\hline & Primary school & 190 & 3.11 & 0.62 & in-group & 229.59 & 521 & 0.44 & & \\
\hline \multirow{3}{*}{$\begin{array}{l}\text { Protective/ } \\
\text { Demanding attitude }\end{array}$} & Middle school & 105 & 2.99 & 0.68 & Total & 235.98 & 525 & & & \\
\hline & High school & 135 & 2.91 & 0.74 & & & & & & \\
\hline & University and above & 36 & 2.92 & 0.72 & & & & & & \\
\hline & Total & 526 & 3.04 & 0.67 & & & & & & \\
\hline & Not a graduate of any school & 60 & 2.31 & 0.73 & Intergroup & 3.24 & 4 & 0.81 & & \\
\hline & Primary school & 190 & 2.19 & 0.76 & in-group & 291.60 & 521 & 0.56 & & \\
\hline Authoritarian & Middle school & 105 & 2.14 & 0.74 & Total & 294.84 & 525 & & 1.45 & 0.22 \\
\hline attitude & High school & 135 & 2.07 & 0.72 & & & & & & \\
\hline & University and above & 36 & 2.02 & 0.84 & & & & & & \\
\hline & Total & 526 & 2.15 & 0.75 & & & & & & \\
\hline
\end{tabular}

According to Table 3., the one-way variance analysis (ANOVA) conducted to determine whether parental attitudes differ significantly with regards to the educational status of the mother indicates that there is no significant difference between the arithmetic averages of the groups for the authoritarian attitude $(\mathrm{F}=1.45 ; \mathrm{p}>.05)$ dimension. However, there was a significant difference between the arithmetic averages of the democratic attitude $(F=3.04 ; p<.05)$ and protective-willing attitude $(F=3.62 ; p<.001)$ dimensions of the parental attitude scale.

Complementary post-hoc analyses were conducted in order to determine between which groups these differences occurred in. The homogeneity of the variances were tested before deciding on which post-hoc technique was to be used, the variances were homogeneous for the democratic attitude $(L=1.59 ; p>.05)$ dimension but were heterogeneous for the protective-willing attitude $(L=2.82 ; p<.05)$ dimension. The Scheffe test was preferred for homogeneous variables and Tamhane's T2 test was preferred for the heterogeneous variances. Results are given below.

Table 3.1. Results for the Scheffe Test Conducted to determine Between Which Groups the Democratic Attitude Dimension Differed according to the Educational Status of the Mother

\begin{tabular}{|c|c|c|c|c|}
\hline Groups (i) & Groups (j) & $\bar{x}_{i}-\bar{x}_{j}$ & $\mathrm{Sh}_{\overline{\mathrm{x}}}$ & $p$ \\
\hline \multirow{4}{*}{ Not a graduate of any school } & Primary school & -.13 & .10 & .76 \\
\hline & Ortaokul & -.01 & .11 & 1.00 \\
\hline & High school & -.22 & .10 & .30 \\
\hline & University and above & -.33 & .14 & .21 \\
\hline \multirow{4}{*}{ Primary school } & Not a graduate of any school & .13 & .10 & .76 \\
\hline & Middle school & .12 & .08 & .68 \\
\hline & High school & -.09 & .07 & .89 \\
\hline & University and above & -.20 & .12 & .58 \\
\hline \multirow{4}{*}{ Middle school } & Not a graduate of any school & .01 & .11 & 1.00 \\
\hline & Primary school & -.12 & .08 & .68 \\
\hline & High school & -.21 & .08 & .18 \\
\hline & University and above & -.31 & .12 & .16 \\
\hline \multirow{4}{*}{ High school } & Not a graduate of any school & .22 & .10 & .29 \\
\hline & Primary school & .09 & .07 & .80 \\
\hline & Middle school & .21 & .08 & .18 \\
\hline & University and above & -.11 & .12 & .94 \\
\hline \multirow{4}{*}{ University and above } & Not a graduate of any school & .33 & .14 & .21 \\
\hline & Primary school & .20 & .12 & .57 \\
\hline & Middle school & .32 & .13 & .16 \\
\hline & High school & .11 & .12 & .94 \\
\hline
\end{tabular}


According to Table 3.1, results for the Scheffe Test conducted to determine between which groups the democratic attitude dimension differed with regards to the educational status of the mother variable show that there were no significant differences. However, according to the LSD analysis, which is a homogeneous test more flexible than Scheffe test, students whose mothers' educational status is at high school level and over perceive their parents more democratic than students whose mothers' educational status is at secondary school level or lower $(\mathrm{p}<.05$ ). The difference between the arithmetic averages of other groups was found insignificant ( $\mathrm{p}>.05)$.

Table 3.2. Results for the Tamhane's T2 Test Conducted to determine Between Which Groups the Protective-Willing Attitude Dimension was Different according to the Educational Status of the Mother

\begin{tabular}{|c|c|c|c|c|}
\hline Groups (i) & Groups (j) & $\bar{x}_{i}-\bar{x}_{j}$ & $\mathrm{Sh}_{\bar{x}}$ & $p$ \\
\hline \multirow{4}{*}{ Not a graduate of any school } & Primary school & 0.14 & 0.08 & 0.66 \\
\hline & Ortaokul & 0.26 & 0.10 & 0.08 \\
\hline & High school & 0.33 & 0.10 & 0.01 \\
\hline & University and above & 0.33 & 0.14 & 0.19 \\
\hline \multirow{4}{*}{ Primary school } & Not a graduate of any school & -0.14 & 0.08 & 0.66 \\
\hline & Middle school & 0.12 & 0.08 & 0.76 \\
\hline & High school & 0.19 & 0.08 & 0.13 \\
\hline & University and above & 0.19 & 0.13 & 0.79 \\
\hline \multirow{4}{*}{ Middle school } & Not a graduate of any school & -0.26 & 0.10 & 0.08 \\
\hline & Primary school & -0.12 & 0.08 & 0.76 \\
\hline & High school & 0.07 & 0.09 & 1.00 \\
\hline & University and above & 0.07 & 0.14 & 1.00 \\
\hline \multirow{4}{*}{ High school } & Not a graduate of any school & -0.33 & 0.10 & 0.01 \\
\hline & Primary school & -0.19 & 0.08 & 0.13 \\
\hline & Middle school & -0.07 & 0.09 & 1.00 \\
\hline & University and above & 0.00 & 0.14 & 1.00 \\
\hline \multirow{4}{*}{ University and above } & Not a graduate of any school & -0.33 & 0.14 & 0.19 \\
\hline & Primary school & -0.19 & 0.13 & 0.79 \\
\hline & Middle school & -0.07 & 0.14 & 1.00 \\
\hline & High school & 0.00 & 0.14 & 1.00 \\
\hline
\end{tabular}

Table 3.2 shows the Tamhane's T2 analysis, which was conducted to determine between which groups the protective-willing dimension scores differed significantly with regards to the educational status of the mother variable, indicates that students whose mother's educational status is at high school level find their parents' attitudes less protective-willing than students whose mothers have no educational degree $(\mathrm{p}<0)$. The difference between the arithmetic averages of other groups was found insignificant ( $\mathrm{p}>.05$ ).

Table 4. Results of the Kruskall Wallis-H Test Conducted to Determine Whether Parental Attitudes Differ According to the Educational Status of the Father

\begin{tabular}{|c|c|c|c|c|c|c|}
\hline Score & Groups & $N$ & $x_{\text {sira }}$ & $x^{2}$ & $s d$ & $p$ \\
\hline \multirow{6}{*}{ Democratic attitude } & Not a graduate of any school & 27 & 169.22 & \multirow{6}{*}{12.85} & \multirow{6}{*}{4} & \multirow{6}{*}{.012} \\
\hline & Primary school & 156 & 266.58 & & & \\
\hline & Middle school & 128 & 264.35 & & & \\
\hline & High school & 137 & 262.69 & & & \\
\hline & University and above & 78 & 289.99 & & & \\
\hline & Total & 526 & & & & \\
\hline \multirow{6}{*}{$\begin{array}{l}\text { Protective/Demanding } \\
\text { attitude }\end{array}$} & Not a graduate of any school & 27 & 282.15 & \multirow{6}{*}{13.35} & \multirow{6}{*}{4} & \multirow{6}{*}{.010} \\
\hline & Primary school & 156 & 295.54 & & & \\
\hline & Middle school & 128 & 262.02 & & & \\
\hline & High school & 137 & 234.47 & & & \\
\hline & University and above & 78 & 246.37 & & & \\
\hline & Total & 526 & & & & \\
\hline \multirow{6}{*}{ Authoritarian attitude } & Not a graduate of any school & 27 & 348.26 & \multirow{6}{*}{11.79} & \multirow{6}{*}{4} & \multirow{6}{*}{.019} \\
\hline & Primary school & 156 & 269.34 & & & \\
\hline & Middle school & 128 & 250.04 & & & \\
\hline & High school & 137 & 266.81 & & & \\
\hline & University and above & 78 & 238.76 & & & \\
\hline & Total & 526 & & & & \\
\hline
\end{tabular}


Table 4 indicates the Kruskall Wallis-H test conducted to determine whether parental attitudes differ with regards to the educational status of the father variable indicates that there is a significant difference between the listed averages of the democratic dimension $(\mathrm{X} 2=12.85 ; \mathrm{p}<.05)$, protective-willing dimension $(\mathrm{X} 2=13.35 ; \mathrm{p}<.05)$ and authoritarian dimension $(\mathrm{X} 2=11.79 ; \mathrm{p}<.05)$. Mann Whitney-U analyses were conducted in order to determine between which groups these differences occurred in. Results are given below.

Table 4. 1. Results of the Mann Whitney-U Analysis Conducted to determine Between Which Groups the Scores of Democratic Attitude Sub-Dimension of the Parental Attitude Scale differed for the Educational Status of the Father Variable

\begin{tabular}{|c|c|c|c|c|c|}
\hline Groups & $\begin{array}{l}\text { Not a graduate of any } \\
\text { school }\end{array}$ & $\begin{array}{c}\text { Primary } \\
\text { school }\end{array}$ & Middle school & High school & $\begin{array}{c}\text { University and } \\
\text { above }\end{array}$ \\
\hline Not a graduate of any school & $\tilde{x}_{\text {sura }}=169.22$ & $p<.01$ & $\mathrm{p}<.01$ & $\mathrm{p}<.01$ & $\mathbf{p}<.01$ \\
\hline Primary school & & $\begin{aligned} & x_{\text {sura }} \\
= & 266.58\end{aligned}$ & $\mathrm{p}>.05$ & $\mathrm{p}>.05$ & $\mathrm{p}>.05$ \\
\hline Middle school & & & $x_{\text {sina }}$ & $\mathrm{p}>.05$ & $\mathrm{p}>.05$ \\
\hline High school & & & $=264.35$ & $\begin{array}{l}\bar{x}_{\text {sura }} \\
=262.69\end{array}$ & p>.05 \\
\hline University and above & & & & & $\bar{x}_{\text {sura }}=289.99$ \\
\hline
\end{tabular}

Table 4.1 shows the Mann Whitney-U analysis, which was conducted to determine whether the scores of the democratic attitude dimension of the parental attitude scale differed significantly for the educational status of the father variable, indicates that students whose fathers do not have an educational degree find their parents less democratic than students whose fathers have an educational degree $(\mathrm{p}<.01)$.

Table 4. 2. Results of the Mann Whitney-U Analysis Conducted to determine Between Which Groups the Scores of Protective-Willing Attitude Sub-Dimension of the Parental Attitude Scale differed for the Educational Status of the Father Variable

\begin{tabular}{|c|c|c|c|c|c|}
\hline Groups & $\begin{array}{l}\text { Not a graduate of } \\
\text { any }=\quad \text { school }\end{array}$ & $\begin{array}{c}\text { Primary } \\
\text { school }\end{array}$ & $\begin{array}{l}\text { Middle } \\
\text { school }\end{array}$ & High school & $\begin{array}{c}\text { University and } \\
\text { above }\end{array}$ \\
\hline Not a graduate of any school & $\bar{x}_{\sin a}=282.15$ & e>.05 & $p>.05$ & $p>.05$ & $\mathrm{p}>.05$ \\
\hline Primary school & & $\begin{array}{l}x_{\text {sura }} \\
=295.54\end{array}$ & $\underline{p}<.05$ & p $<.01$ & p<.05 \\
\hline Middle school & & & $\begin{array}{l}\bar{x}_{\text {sura }} \\
=26202\end{array}$ & $p>.05$ & $\mathrm{p}>.05$ \\
\hline High school & & & & $\begin{array}{l}\bar{x}_{\text {sura }} \\
=234.47\end{array}$ & $p>.05$ \\
\hline University and above & & & & $=254.41$ & $\bar{x}_{\text {sura }}=246.37$ \\
\hline
\end{tabular}

Table 4.2. shows the Mann Whitney-U analysis, which was conducted to determine whether the scores of the protective-willing attitude dimension of the parental attitude scale differed significantly for the educational status of the father variable, indicates that students whose fathers are primary school graduates find their parents more protective-willing than the students whose fathers are secondary school $(\mathrm{p}<.05)$, high school $(\mathrm{p}<.01)$ and university and over graduates $(\mathrm{p}<.05)$.

Table 4. 3. Results of the Mann Whitney-U Analysis Conducted to determine Between Which Groups the Scores of Authoritarian Attitude Sub-Dimension of the Parental Attitude Scale differed for the Educational Status of the Father Variable

\begin{tabular}{|c|c|c|c|c|c|}
\hline Groups & $\begin{array}{c}\text { Not a } \\
\text { graduate of any } \\
=\quad \text { school }\end{array}$ & $\begin{array}{c}\text { Primary } \\
\text { school }\end{array}$ & $\begin{array}{c}\text { Middle } \\
\text { school }\end{array}$ & High school & $\begin{array}{c}\text { University and } \\
\text { above }\end{array}$ \\
\hline Not a graduate of any school & $x_{\operatorname{sur} a}=348.26$ & $p<.01$ & $\mathrm{p}<.01$ & $p<.05$ & $p<.01$ \\
\hline Primary school & & $\begin{array}{c}x_{\text {sura }} \\
=269.34\end{array}$ & $\mathrm{p}>.05$ & $\mathrm{p}>.05$ & $\mathrm{p}>.05$ \\
\hline Middle school & & & $\begin{array}{c}\bar{x}_{\text {sura }} \\
=250.04\end{array}$ & $\begin{array}{l}p>.05 \\
\overline{-}\end{array}$ & $\mathrm{p}>.05$ \\
\hline High school & & & & $\begin{array}{c}\bar{x}_{\text {sura }} \\
=266.81\end{array}$ & $p>.05$ \\
\hline University and above & & & & & $x_{\operatorname{sur} a}=238.76$ \\
\hline
\end{tabular}

Table 4.3. shows the Mann Whitney-U analysis, which was conducted to determine whether the scores of the authoritarian attitude dimension of the parental attitude scale differed significantly for the educational status of the father variable, indicates that students whose fathers have no educational degree find their parents more authoritarian than the students whose fathers are primary school $(\mathrm{p}<.01)$, secondary school $(\mathrm{p}<.01)$, high school $(\mathrm{p}<.05)$ and university or over graduates $(\mathrm{p}<.01)$. 
Table 5. Results of the One-Way Variance Analysis (ANOVA) Conducted to Determine Whether Parental Attitudes Differ According to the Number of Siblings

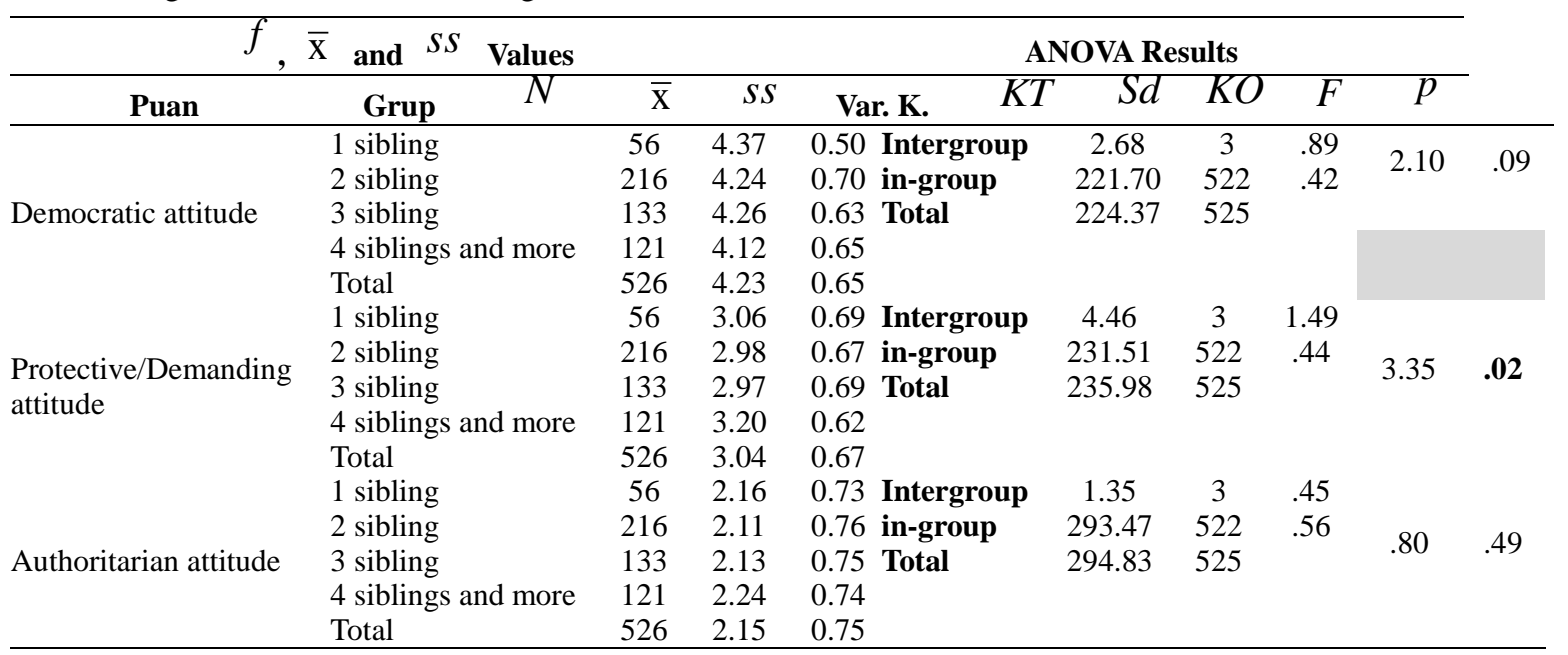

Table 5. shows the one-way variance analysis (ANOVA) conducted to determine whether parental attitudes differ significantly with regards to the number of siblings the students has, indicates that there is no significant difference between the arithmetic averages of the groups for the democratic attitude dimension $(\mathrm{F}=2.10 ; \mathrm{p}>.05)$ and the authoritarian attitude $(\mathrm{F}=3.35 ; \mathrm{p}>.05)$ dimension. However, there was a significant difference between the arithmetic averages of the protective-willing attitude $(\mathrm{F}=3.04 ; \mathrm{p}<.05)$ dimension of the parental attitude scale. Complementary post-hoc analyses were conducted in order to determine between which groups these differences occurred in. The homogeneity of the variances were tested before deciding on which post-hoc technique was to be used, the variances were homogeneous for the protective-willing attitude $(\mathrm{L}=0.74 ; \mathrm{p}>.05)$ dimension. Because the variance was homogeneous the Scheffe test was preferred and the results are given below.

Table 5.1. Results for the Scheffe Test Conducted to determine Between Which Groups the Protective-Willing Attitude Dimension Differed according to the Number of Siblings Variable

\begin{tabular}{|c|c|c|c|c|}
\hline Groups (i) & Groups (j) & $x_{i}-x_{j}$ & $\mathrm{Sh}_{\overline{\mathrm{x}}}$ & $p$ \\
\hline \multirow{3}{*}{1 sibling } & 2 siblings & 0.08 & 0.10 & 0.89 \\
\hline & 3 siblings & 0.08 & 0.11 & 0.89 \\
\hline & 4 siblings and more & -0.14 & 0.11 & 0.64 \\
\hline \multirow{3}{*}{2 siblings } & 1 sibling & -0.08 & 0.10 & 0.89 \\
\hline & 3 siblings & 0.00 & 0.07 & 1.00 \\
\hline & 4 siblings and more & -0.22 & 0.08 & 0.04 \\
\hline \multirow{3}{*}{3 siblings } & 1 sibling & -0.08 & 0.11 & 0.89 \\
\hline & 2 siblings & 0.00 & 0.07 & 1.00 \\
\hline & 4 siblings and more & -0.22 & 0.08 & 0.07 \\
\hline \multirow{3}{*}{4 siblings and more } & 1 sibling & 0.14 & 0.11 & 0.64 \\
\hline & 2 siblings & 0.22 & 0.08 & 0.04 \\
\hline & 3 siblings & 0.22 & 0.08 & 0.07 \\
\hline
\end{tabular}

Table 5., shows that the results of the Scheffe test, which was conducted in order to determine between which groups the protective-willing attitude scores differed with regards to the number of sibling variable, indicate that students with 4 or more siblings find their parents more protective-willing than students with 2 siblings $(\mathrm{p}<.05)$ The difference between the arithmetic averages of other groups was found insignificant ( $p>.05)$. 
Table 6. Results of the One-Way Variance Analysis (ANOVA) Conducted to Determine Whether Parental Attitudes Differ According to the Perceived Level of Income

\begin{tabular}{|c|c|c|c|c|c|c|c|c|c|c|}
\hline & $f, \overline{\mathrm{x}}$ and $s S$ Values & & & & \multicolumn{6}{|c|}{ ANOVA Results } \\
\hline Score & Group & 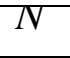 & $\overline{\mathrm{X}}$ & $S S$ & Var. K. & $K T$ & $S d$ & KO & $F$ & $p$ \\
\hline \multirow{4}{*}{ Democratic attitude } & Low and below middle class & 73 & 4.10 & 0.78 & Intergroup & 1.99 & 2.00 & 0.99 & & \\
\hline & Middle class & 314 & 4.23 & 0.63 & in-group & 222.39 & 523. & 0.43 & 2.34 & 0.10 \\
\hline & Upper and high & 139 & 4.30 & 0.63 & Total & 224.38 & 525. & & & \\
\hline & Total & 526 & 4.23 & 0.65 & & & & & & \\
\hline \multirow{4}{*}{$\begin{array}{l}\text { Protective/Demanding } \\
\text { attitude }\end{array}$} & Low and below middle & 73 & 3.18 & 0.58 & Intergroup & 1.87 & 2 & 0.94 & & \\
\hline & Middle class & 314 & 3.01 & 0.71 & in-group & 234.11 & 523 & 0.45 & 2.09 & 0.13 \\
\hline & Upper and high & 139 & 3.03 & 0.62 & Total & 235.98 & 525 & & & \\
\hline & Total & 526 & 3.04 & 0.67 & & & & & & \\
\hline \multirow{4}{*}{ Authoritarian attitude } & Low and below middle class & 73 & 2.33 & 0.81 & Intergroup & 2.66 & 2 & 1.33 & & \\
\hline & Middle class & 314 & 2.12 & 0.75 & in-group & 292.18 & 523 & 0.56 & 2.38 & 0.09 \\
\hline & Upper and high & 139 & 2.12 & 0.71 & Total & 294.84 & 525 & & & \\
\hline & Total & 526 & 2.15 & 0.75 & & & & & & \\
\hline
\end{tabular}

Table 6., shows the one-way variance analysis (ANOVA) conducted to determine whether parental attitudes differ significantly with regards to the perceived level of income variable, indicates that there is no significant difference between the arithmetic averages of the groups for the democratic attitude dimension $(\mathrm{F}=2.34 ; \mathrm{p}>.05)$, protective-willing attitude dimension $(\mathrm{F}=2.09 ; \mathrm{p}>.05)$ and authoritarian attitude $(\mathrm{F}=2.38 ; \mathrm{p}>.05)$ dimension.

Table 7.

Results of the Mann Whitney-UTest Conducted to Determine Whether Parental Attitudes Differ According to the Whether Parents are Alive Variable

\begin{tabular}{|c|c|c|c|c|c|c|c|}
\hline Score & Groups & $N$ & $\bar{x}_{\text {sira }}$ & $\sum_{s i r a}$ & $U$ & $z$ & $p$ \\
\hline \multirow{3}{*}{ Democratic } & Alive & 514 & 265.70 & 136572 & \multirow{3}{*}{1951} & \multirow{3}{*}{-2.18} & \multirow{3}{*}{.029} \\
\hline & Dead & 12 & 169.08 & 2029 & & & \\
\hline & Total & 526 & & & & & \\
\hline \multirow{3}{*}{$\begin{array}{l}\text { Protective/ } \\
\text { Demanding }\end{array}$} & Alive & 514 & 263.43 & 135402 & \multirow{3}{*}{3047} & \multirow{3}{*}{-.071} & \multirow{3}{*}{.943} \\
\hline & Dead & 12 & 266.58 & 3199 & & & \\
\hline & Total & 526 & & & & & \\
\hline \multirow{3}{*}{ Authoritarian } & Alive & 514 & 263.84 & 135611.5 & \multirow{3}{*}{2911.5} & \multirow{3}{*}{-.332} & \multirow{3}{*}{.740} \\
\hline & Dead & 12 & 249.13 & 2989.5 & & & \\
\hline & Total & 526 & & & & & \\
\hline
\end{tabular}

Table 7 shows that according to the results of the Mann Whitney-U Test, which was conducted to determine whether the averages of the parental attitudes scale of sample students differ with regards to whether parents are alive variable, no significant differences for the listed group averages were determined for the protective $(\mathrm{z}=-., 071 ; \mathrm{p}>.05)$ and authoritarian ( $\mathrm{z}=-.332 ; \quad \mathrm{p}>.05)$ attitude dimensions; but a significant difference was identified for the listed group averages for the democratic attitude $(\mathrm{z}=-2.18 ; \mathrm{p}<.05)$ dimension. In other words, students whose both parents are alive find their parents' attitudes more democratic than students who have lost at least one parent.

Table 8. Results of the Independent Samples T Test Conducted to Determine Whether Parental Attitudes Differ according to the Marital Status of the Parents

\begin{tabular}{|c|c|c|c|c|c|c|c|c|}
\hline \multirow{2}{*}{ Score } & \multirow{2}{*}{ Groups } & \multirow{2}{*}{$N$} & \multirow{2}{*}{$\overline{\mathrm{X}}$} & \multirow{2}{*}{$s S$} & \multirow{2}{*}{$\mathrm{Sh}_{\overline{\mathrm{x}}}$} & \multicolumn{3}{|c|}{$t \quad$ Test } \\
\hline & & & & & & $t$ & $S d$ & $p$ \\
\hline \multirow{2}{*}{ Democratic attitude } & Married & 490 & 4.25 & 0.64 & 0.029 & \multirow{2}{*}{2.122} & \multirow[b]{2}{*}{524} & \multirow{2}{*}{.034} \\
\hline & Divorced & 36 & 4.01 & 0.81 & 0.13 & & & \\
\hline \multirow{2}{*}{ Protective/Demanding attitude } & Married & 490 & 3.04 & 0.66 & 0.03 & \multirow{2}{*}{.884} & \multirow{2}{*}{524} & \multirow{2}{*}{.377} \\
\hline & Divorced & 36 & 2.94 & 0.75 & 0.13 & & & \\
\hline \multirow{2}{*}{ Authoritarian attitude } & Married & 490 & 2.14 & 0.73 & 0.03 & \multirow[b]{2}{*}{-.745} & \multirow[b]{2}{*}{524} & \multirow[b]{2}{*}{.457} \\
\hline & Divorced & 36 & 2,24 & 0.94 & 0.17 & & & \\
\hline
\end{tabular}

Table 8 shows that according to the Independent Samples T Test, which was conducted to determine whether parental attitudes differ with regards to the marital status of the parents variable, there is no significant difference between the arithmetic averages of the groups of the authoritarian attitude $(\mathrm{t}=-.745 ; \mathrm{p}>.05)$ dimension and the protective-willing attitude $(\mathrm{t}=.884 ; \mathrm{p}>.05)$ dimension. However, the difference between the arithmetic averages of the groups for the 
democratic attitude dimension was significantly in favor of the students whose parents are married $(t=2.122 ; \mathrm{p}<.05)$. In other words, students whose parents are married find their parents' attitudes more democratic than the students whose parents are divorced.

\section{Discussion and Conclusion}

This study, which aimed at analyzing parental attitudes that secondary school students perceive according to specific variables, identified no significant differences between democratic and protective-willing attitudes sub-dimensions and the gender of students. However, with regards to the authoritarian attitude sub-dimension of the parental attitudes dimension, male students found their parents more authoritarian than female students.

According to Yllmaz's (2009) study, male students find their parents' attitudes more authoritarian than female students. Zengin (2008) found that parental attitudes were more favorable for male students for the all 3 sub-dimensions.

With regards to the educational status of the mother variable, the difference between authoritarian attitudes and the educational status of the mother was not found significant. However, there was a significant difference between democratic attitude and protective-willing attitude and the educational status of the mother variable. According to the analyses results; students whose mother's educational status is high school, university or over perceive their parents' attitudes more democratic than students whose mothers have no educational degree or are secondary school graduates. Students whose mothers are high school graduates find their parents' attitudes less protective-willing than students whose mothers have no educational degree.

According to Durmus (2006) conducted, families in which the mother is a university graduate display less protective-willing attitudes to their children than families in which the mother is a primary school graduate. According to the study which Sertelin (2003) conducted, democratic attitudes towards children increase in families in which the mothers' educational status is high. Mothers who display democratic attitudes most are university graduates. Yilmazer (2007) states that an increase in the tendency to show interest and acceptance occurs as the educational status of the mother increases. With regards to the educational status of the father variable, there was a significant relationship between all the parental attitudes sub-dimensions and the educational status of the father. According to the analyses results; students whose father have no educational degree perceive their parents' attitudes less democratic than students whose fathers have an educational degree. Students whose fathers are primary school graduates find their parents' attitudes more protective-willing than students whose fathers are secondary school, high school, university graduates and post-graduates. Students whose fathers have no educational degree find their parents' attitudes more authoritarian than students whose fathers are primary school, secondary school, high school, university graduates and post-graduates.

According to Yilmazer (2007), the educational status of the father increases, the acceptance and psychological autonomy attitudes increase as well. Zengin (2008), Ozyurek and Sahin (2005) state in their studies that students perceive their parents as more democratic as the educational status of their fathers increase. Tosuntas's (2006) study suggests that social skills of children enhances as the educational status of the fathers increase. When parental attitudes are concerned according to the number of siblings, there were no significant differences between number of siblings and authoritarian attitudes. A significant difference was identified between protective-willing parents and the number of siblings. According to the analyses, students with 4 or more siblings find their parents' attitudes more protective-willing than students with 2 siblings.

According to other studies on this subject, Sertelin (2003) points out that there was a significant relationship between the numbers of siblings of students who perceive their mothers as overprotective. The mother displays a more protective manner when the number of siblings increases. According to Gokcedag's (2001) study, authoritarian attitudes increase in families in which the numbers of children are high. According to the study findings, with regards to parental attitudes and income levels there was a significant difference between all sub-dimensions of parental attitudes. Aktas (2011) found no significant differences between sub-dimensions of parental attitudes and income levels of the families. Demiriz et al. (2007) state that although there are no significant differences between protective-willing and authoritarian attitudes, for the democratic attitudes dimension only the differences for low income levels were found significant. Mothers in families with low income levels are less compatible and stricter.

When parental attitudes are concerned according to whether parents are alive, there were no significant differences between protective-willing and authoritarian attitudes and whether parents are alive or not. However, the difference between whether parents are alive and democratic attitude sub-dimension of parental attitudes was found significant. Analyses indicate that students whose both parents are alive perceive their parents' attitudes more democratic than students who have lost at least one parent.

According to Yavuz (2009), students who have lost one of their parents embrace violence more than students whose parents live together. When parental attitudes are concerned according to the marital status of the parents, there were no 
significant differences between protective-willing and authoritarian attitudes and the marital status of the parents. However, there was a significant difference between democratic attitude and the marital status of parents. According to the analyses, it can be asserted that students whose parents are married perceive their parents' attitudes more democratic than students whose parents have divorced.

According to Hatun (2012), reassuring-supportive agents state that children who define their mothers' attitudes as oppressive-authoritarian and overprotective perceive problem solving and communication roles of the family as unhealthy. According to the study conducted by Mack (2001), children whose parents live separately have more problems in the future than children whose parents are married.

\section{Recommendations}

According to the results of the study; seminars on parental attitudes should be arranged at schools by psychological counselors, municipal authorities should arrange seminars on parental attitudes by professionals according to the age groups of the students. Families with too many children should be prioritized for the seminars which will be arranged according to the findings. The psychological counselor should make face-to-face interviews with families on how parental attitudes affect the child and what kind of influences it will have in the future. Parents who have lost their partners or who have been divorced should be informed about how to approach the child in a more democratic manner. In addition, in order to enter into good relationships with the children, contribute to their personal development and to support the adolescent to experience a healthy mood; Ministry of Education, universities, municipalities, Public Education centers and NGO's should execute; training programs on child psychology, adolescence period, protecting mental health, personality development to expectant couples and to all adults.

\section{Contribution}

This paper is produced from author's MA Thesis.

\section{References}

Aktas, S. (2011). 9. Sinifta anne baba tutumlari ve benlik saygisi arasindaki iliskinin bazi degiskenler acisindan incelenmesi. Yayinlanmamis Yuksek Lisans Tezi, Selcuk Universitesi, Konya.

Baltas, A. (2003). Egitim basarisini yukseltmede, saglikli ve mutlu insanlar yetistirmede ailenin rolu: Ana-baba okulu. (10. Baski), Istanbul: Remzi Kitapevi.

Bayraktar, F. (2007). Olumlu ergen gelisiminde ebeveyn/akran iliskilerinin onemi. Cocuk ve Genclik Ruh Sagligi Dergisi, 14(3),157-66.

Birsen, P. (2008). Dusunme stilleri ve anne-baba tutumlari arasindaki iliski. Dokuz Eylul Buca Egitim Fakultesi Dergisi, 24, 1-11.

Branch, C. W. (1986). Racial attitude development among young black children as a function of parental attitudes: A longitudinal and cross-sectional study. Child Development, 57, 712-721. http://dx.doi.org/10.2307/1130348

Budd, K. S., Behling, S., Li, Y., Parikshak, S., Gershenson, R. A., Feuer, R., \& Danko, C. M. (2012). Measuring attitudes toward acceptable and unacceptable parenting practices. Journal of Child and Family Studies, 21(2), 247-261. http://dx.doi.org/10.1007/s10826-011-9470-3

Creswell, J. W. (2012). Qualitative Inquiry and Research Design: Choosing among Five Approaches. Thosandoaks, CA: Sage Press.

Demiriz, S., \& Ogretir, A. D. (2007). Alt ve ust sosyo-ekonomik duzeydeki 10 yas cocuklarinin anne tutumlarinin incelenmesi. Kastamonu Egitim Dergisi, 15(1), 105-122.

Durmus, R. (2006). 3-6 yas arasi cocugu olan ebeveynlerin kisilik ozellikleri ile anne-baba tutumlarinin bazi degiskenlere gore incelenmesi. Yayinlanmamis Yuksek Lisans Tezi, Marmara Universitesi, Istanbul.

Eldeleklioglu, J. (2004). Cocuklarda ozguven gelisimi. Gazi Universitesi Egitim Fakultesi Dergisi, 24(2), 111-12

Erdogan, O., \& Ucukoglu, H. (2011). Ilkogretim okulu ogrencilerin anne-baba tutumu algilari ile atilganlik ve olumsuz degerlendirilmekten korkma duzeyleri arasindaki iliskiler. Kastamonи Egitim Dergisi, 19(1), 51-72.

Gokcedag, S. (2001). Lise ogrencilerinin okul basarisi ve kaygi duzeyi uzerinde anne-baba tutumlarinin etkilerinin belirlenip karsilastirilmasi. Yayinlanmamis Yuksek Lisans Tezi, Dokuz Eylul Universitesi, İzmir.

Gulacti, F. (2009). Sosyal beceri egitimine yonelik bir grup rehberligi programinin ogrencilerin, oznel ve psikolojik iyi olma duzeylerine etkisi. Yayinlanmamis Doktora Tezi, Ataturk Universitesi, Erzurum.

Hatun, O. (2012). Anne babasi bosanmis ilkogretim ikinci kademe ogrencilerinin algiladiklari aile islevlerinin bazi degiskenler acisindan incelenmesi: Istanbul ili (Fatih Ilcesi Ornegi). Yayinlanmamis Yuksek Lisans Tezi, Yeditepe 
Universitesi, Istanbul.

Hummel, R. M., \& Gross, A. M. (2001). Socially anxious children: An observational study of parent-child interaction. Child \& Family Behavior Therapy, 23, 19-42. http://dx.doi.org/10.1300/J019v23n03_02

Karasar, N. (2014). Bilimsel arastirma yontemi. (27. Baski), Ankara: Nobel Akademik Yayincilik.

Kaya, A., Bozaslan, H., \& Genc, G. (2012). Universite ogrencilerinin anne-baba tutumlarinin problem cozme becerilerine, sosyal kaygi duzeylerine ve akademik basarilarina etkisi. Dicle Universitesi Ziya Gokalp Egitim Fakultesi Dergisi, 18, 208-225.

Kilicaslan, A. (2001). Aile fonksiyonlarinin ve algilanan farklilasmis anne-baba yaklasiminin kardes iliskileri uzerindeki etkisi. Yayinlanmamis Yuksek Lisans Tezi, Istanbul Universitesi, Istanbul.

Kulaksizoglu, A. (2008). Ergenlik psikolojisi. (10. Baski), Istanbul: Remzi Kitabevi.

Kuzgun, Y., \& Eldeleklioglu, J. (2005). Anne-baba tutumlari olcegi. Edit: Kuzgun ve F. Bacanli: PDR'de kullanilan olcekler. Ankara: Nobel Yayin Dagitim.

Mack, K. Y. (2001). Childhood family disruptions and adult well-being: The differential effects of divorce and parental death. Death studies, 25(5), 419-443. http://dx.doi.org/10.1080/074811801750257527

Ozguven, E. I. (2001). Ailede iletisim ve yasam. Ankara: PDREM Yayinlari.

Ozyurek, A., \& Sahin, F. T. (2005). 5 ve 6 yas grubunda cocugu olan ebeveynlerin tutumlarinin incelenmesi. Gazi Egitim Fakultesi Dergisi, 25(2).

Parker, G., \& Roy, K. (2001). Adolescent depression: a review. $N \quad Z \quad J$ Psychiatry, $35, \quad 572$. http://dx.doi.org/10.1080/0004867010060504

Peterson, D. R. (1961). Behavior problems of middle childhood. Journal of Consulting Psychology, $25(3), 205$. http://dx.doi.org/10.1037/h0038994

Sargin, N. (2001). Cocuklarda ruh sagligi. Ankara: Nobel yayin Dagitim.

Sertelin, C. (2003). Aile tutumlarinin sosyo-kulturel yapi ve aile fonksiyonlari ile iliskisi. Yayinlanmamis Yuksek Lisans Tezi, Istanbul Universitesi, Istanbul.

Tosuntas, F. (2006). Ergenlerde algilanan duygusal istismar ile sosyal beceri arasindaki iliski. Yayinlanmamis Yuksek Lisans Tezi, Marmara Universitesi, Istanbul.

Yavuz, N. (2009). Ilkogretim 7 ve 8. sinif ogrencilerinin siddet egilimlerinin cesitli degiskenler acisindan incelenmesi. Yayinlanmamis Yuksek Lisans Tezi, Yeditepe Universitesi, Istanbul.

Yavuzer, H. (2011). Cocuk ve suc. (14. Baski), Istanbul: Remzi Kitabevi.

Yavuzer, H. (2012). Cocuk psikolojisi. (34. Baski), Istanbul: Remzi Kitabevi.

Yavuzer, H. (2013). Cocuk ve ergen egitiminde anne baba tutumlari. (4. Baski), Istanbul: Timas Yayinlari.

Yilmaz, A. (2009). Ilkogretim sekizinci sinif ogrencilerinin anne baba tutumlari ile kararsizlik duzeyleri arasindaki iliski. Yayinlanmamis Yuksek Lisans Tezi, Yeditepe Universitesi, Istanbul.

Yilmazer, Y. (2007). Anne baba tutumlari ile ilkogretim ikinci kademe ogrencilerinin okul basarisi ve ozerkliklerinin gelisimi arasindaki iliskinin incelenmesi. Yayinlanmamis Yuksek Lisans Tezi, Hacettepe Universitesi, Ankara.

Yorukoglu, A. (2011). Cocuk ruh sagligi / cocuk yetistirme sanati ve kisilik gelisimi. (31. Baski), Istanbul: Ozgur Yayinlari.

Zengin, E. (2008). Anne baba tutumlari ile adolesan saldirganligi arasindaki iliskinin incelenmesi. Yayinlanmamis Yuksek Lisans Tezi, Ataturk Universitesi, Erzurum.

This work is licensed under a Creative Commons Attribution 3.0 License. 